\title{
L. M. Montgomery Censored? : Canadian War Commentary in Rilla of Ingleside Adapted for Nordic Audiences
}

\section{Leden, Laura Irene}

2017

Leden , L I 2017 , ' L. M. Montgomery Censored? Canadian War Commentary in Rilla of Ingleside Adapted for Nordic Audiences ' , Lion and the unicorn : a critical journal of children's literature , vol. 41 , no. 2 , pp. 143-166 . https://doi.org/10.1353/uni.2017.0015

http://hdl.handle.net/10138/308192

https://doi.org/10.1353/uni.2017.0015

unspecified

publishedVersion

Downloaded from Helda, University of Helsinki institutional repository.

This is an electronic reprint of the original article.

This reprint may differ from the original in pagination and typographic detail.

Please cite the original version. 


\section{PROJECT MUSE}

L. M. Montgomery Censored?: Canadian War Commentary in Rilla of Ingleside Adapted for Nordic Audiences

Laura Leden

The Lion and the Unicorn, Volume 41, Number 2, April 2017, pp. 143-166 (Article)

Published by Johns Hopkins University Press

DOI: https://doi.org/10.1353/uni.2017.0015

$\Rightarrow$ For additional information about this article https://muse.jhu.edu/article/677543 


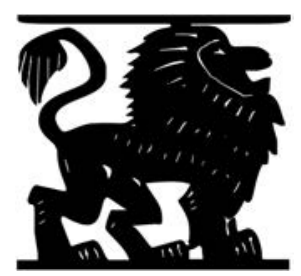

\section{“L. M. Montgomery Censored? Canadian War Commentary in Rilla of Ingleside Adapted for Nordic Audiences"}

\section{Laura Leden}

Rilla of Ingleside (1921), a novel about heroism and womanhood, and the final book in L. M. Montgomery's (1874-1942) Anne of Green Gables series (1908-21), ${ }^{1}$ is known as the only novel by a woman about the Canadian home front during the First World War that has retained a readership until today (Epperly 112; McKenzie 86). In Rilla of Ingleside, Montgomery incorporates two crucial messages about the First World War: she describes women as heroes on the home front comparable to the heroic men at the front and advocates the righteousness of the Great War from a patriotic Canadian perspective.

In recent years, Rilla of Ingleside has been a popular topic in Montgomery studies, not least at the L. M. Montgomery and War conference in 2014, commemorating the beginning of the First World War. In 2010, a new, complete special edition was published with background material and a thorough introduction by the Montgomery scholars Benjamin Lefebvre and Andrea McKenzie on the significance of the book, and in 2016, Montgomery's original manuscript showing her revisions was published edited by Elizabeth and Kate Waterston.

This article discusses how the war and gender-related messages have been adapted and even censored in Nordic translations of the book by changing how different nationalities are referred to and by minimizing the role of an important female character, Susan Baker, the maid of the protagonist's family. Three considerations drive these adaptations: the tense political situations of the countries in which the books were translated, the availability of already-translated source texts other than the original $\mathrm{Ca}$ nadian manuscript, and a restrictive understanding of children's literature as "innocent" material for younger audiences that should be expurgated of 
"adult" issues. Examining how war is reflected in these translations reveals how political history and the time of translation affect each version of the book published in different Nordic countries. The translations give the reader information about the time and place in which the novel was set, the time and place in which the novel was originally composed, and the time and place from (and for) which the translator is adapting the text.

To date, translations of Rilla of Ingleside (1921) have been published in four Nordic countries: Sweden (1928), Norway (1959), Finland (1962), and Denmark (1993). ${ }^{2}$ In addition to these Nordic translations, I will discuss the German translation (1995-96) for comparison, because of the adaptations relating to Germany and Germans made in the three early Nordic translations and because of Germany's close geographical and cultural ties to the Nordic countries. Major adaptation occurs only in the three oldest translations. The slightly abridged, politically almost neutral Swedish translation introduced Rilla of Ingleside to the Nordic countries and served as a source text for the two other early translations. The Norwegian translation abridges the Swedish translation and thus does not reflect Norwegian post-Second World War anti-German sentiment, while the Finnish translation can be considered an adapted version of the Swedish translation influenced by Finland's political history and the pacifist movement of the 1960s resulting in a reduced emphasis on nationality.

In all three early translations, the adaptation of war-related elements is closely connected to diminishment of the character of Susan, and with it, her female heroism. Montgomery uses Susan as the most vocal descriptor of the war: she either articulates or participates in all of the crucial discussions about the war in Europe and its impact on the local community. Consequently, the translations that omit or alter Susan's part in the narrative clearly reflect the translator's or publisher's opinions about the war and about female characters. Therefore, the analysis of translations of Rilla of Ingleside in this article will focus on how they manage Susan's commentary on the war. ${ }^{3}$ With more distance from the world wars and the rise of feminist thought, modern translators are free to break from earlier constraints and translate Montgomery's text more explicitly as a Canadian wartime story. The more recent Danish and German translations make hardly any omissions or other adaptations and exemplify this change in translation norms.

\section{Messages about War-Time Heroism and Gender Roles in Montgomery's Original Rilla of Ingleside}

In Rilla of Ingleside, Montgomery describes Canadian home front life through the eyes of female characters, making the novel an expression of female 
heroism. Andrea McKenzie describes the novel as a female version of the male war myth (84). This traditional war myth concerns the sacrifices of a generation of young men for a better world, while Montgomery describes the sacrifices of women (84). As the title indicates, Anne's teenage daughter Rilla Blythe is the main protagonist, but the Blythe family's maid Susan Baker also becomes an important observer of the war. Rilla and Susan are the heroines of the book and represent two sides of female heroism in wartime. Anne, the main character of the earlier books, retreats from the story, taking a passive role, while her daughter and servant advance to take active and dynamic roles.

A spoiled teenager at the beginning of the book, Rilla matures and grows into heroism by losing her vanity, working hard to run the junior Red Cross society, and learning about grief and loss through the death of her favorite brother. Key to her maturation is taking responsibility by adopting a war baby. Rilla is a young poetic heroine who represents a traditional romanticized girls' Bildungsroman heroine going through a feminine maturation process.

In Montgomery's original text, Susan, an old maid at the respectable age of sixty-four years, functions as a contrast to Rilla and can be interpreted as a feminist heroine disguised as a comic foil. She is often described in comic situations arising from what Erika Rothwell calls the combination of two opposed discourses: the domestic and the political (137). Being only the maid of the household, Susan is an unconventional heroine. She is the one who keeps the household running throughout the war. In previous Montgomery scholarship, Susan rather than Rilla is used to draw parallels between women and war heroism: Elizabeth Epperly calls Susan "a staunch woman warrior spirit of Canada" (125), and according to Elizabeth Waterston, Susan "epitomized the staunch response of women to the war" (Magic Island 107).

Susan develops at least as much as Rilla during the novel, since she "broadens her perspective from the domestic to the world stage" (95), as McKenzie puts it. At the beginning of the book, Susan knows nothing about the world outside her small home village, but throughout the book she becomes increasingly interested in the world events that she learns about in newspapers. Susan is the strongest female character in the book, and her development parallels that of a traditional girls' Bildungsroman heroine. In contrast to Rilla, however, Susan enters traditionally masculine domains in her learning process. Susan crosses the gender boundaries of her time by taking an active role in politics, strongly judging the actions of world politicians, and arguing with males in her community. Susan becomes an important female role model for girls and young women alongside Rilla.

Susan and Rilla together personify the Canadian home front perspective of a novel that expresses strong patriotic messages. This is not surprising, since Montgomery began writing Rilla of Ingleside a few months after the 
end of the First World War, and the book was published only three years after the end of the war (Montgomery, Selected Journals II 309). Thus, it was a contemporary novel strongly influenced by contemporary ideas about the war. The novel takes an emphatic stand for the Allies and in particular the Canadian efforts in the war. The patriotism is most vocally expressed through Susan, who is very loyal to the Blythe family as well as to her mother country Canada. Love of home is a typical theme in Montgomery's novels, as many of the titles of her novels, such as Rilla of Ingleside or Anne of Green Gables, strongly indicate. In Susan's case, love of home is symbolized by her constantly translating the foreign into something local that she can relate to, as Epperly points out (126). Susan becomes a symbol of patriotism, because she never stops believing in victory; she is the one to hoist the flag whenever there is good war news, and late in the book she is depicted in two highly patriotic scenes: working in the fields instead of the absent men, and taking an active role in local politics by making a heated speech to encourage donations to a Victory Loan Campaign. Since all these are traditionally male activities, Susan's patriotism shows her stepping outside her gender role. Thus, her actions contrast with the conservative political opinions she expresses, as Rothwell argues (138). Susan is the main source of comic but sometimes harsh war commentary, which is another traditionally male attribute. She is very prejudiced against other nationalities and treats Germany and Germans, the enemy, extremely disrespectfully by referring to them by the abusive term "Huns." Her speeches clearly present Canadians as good and Germans as evil. From today's perspective, some of her comments could be called politically incorrect.

Because the novel presents the war as righteous and necessary, pacifism is described in very negative terms, as exemplified by the treatment of the eccentric Mr Pryor, called Whiskers-on-the-Moon by members of the community. According to Susan, who indicates that she does not understand the concept, pacifism "is nothing proper or Whiskers would not be it" (126). In Susan's terms, pacifism is the same as being pro-German, and the entire community accepts a beating of Mr Pryor because he uttered a pacifist prayer. The novel's anti-pacifism supports the novel's general message about the righteousness of the war, which in turn supports the message of female heroism during the war. These messages are changed in the early Nordic translations not only to reflect each country's political situation at the time of translation but also to reflect stricter gender roles. 


\section{Norms, Adaptation, and Censorship \\ in the Translation of Children's Literature}

The Nordic translations of Rilla of Ingleside and decisions about what to adapt are influenced by the translation norms for children's literature at the time of each translation as well as by the prevailing views on children, childhood, the purpose of children's literature, and what is considered appropriate for children. Montgomery's books were not originally written and marketed for children only; children were Montgomery's core audience, but at the time of publication her books were read by adults too, particularly women (see, for example, Lefebvre 6-7). An advertisement for Rilla of Ingleside from 1921 states that the novel "appeals to young girls of 15 to 20 as well as their elders" (Lefebvre i). However, in translation in the countries discussed here, the book was targeted exclusively at children, as all translations discussed are published by publishers specializing in children's literature. Thus, it is important to analyze the translations in this context, because all adaptation or censoring has been carried out with the target child reader in mind.

Isabelle Desmidt points out that translation of children's literature follows the same norms as translation of literature for adults, with two important additions (86). Children's literature translations not only observe source text related equivalence norms, literary norms, and commercial norms, but they also incorporate didactic and pedagogical norms (86). These two child-specific norms have affected the Nordic Montgomery translations particularly strongly. Didactic norms mean that children's books should enhance the intellectual and emotional development of the child and set good, worthy examples, by changing the source text if necessary (Desmidt 86). In the early Nordic translations of Rilla of Ingleside, these norms are seen, for example, in the translations' reflection of the target country's political views, and in the reduction of Susan's role because she steps outside her gender role. Translation to observe pedagogical norms requires adjustment to the language skills and conceptual knowledge of the child, for example, by adapting cultural elements (Desmidt 86). In the translations of Rilla of Ingleside, references to historical persons related to the war and unfamiliar to the target readers have been omitted. The didactic and pedagogical norms have different implications at different times and in different cultures. Because these norms often require adaptation, they clash with the norms of equivalence between source and target texts, which are considered the most important norms today (Desmidt 86). Considerations of didactic and pedagogical norms for children's literature have demonstrably resulted in adaptation or even censorship in the early Nordic translations of Rilla of Ingleside. 
Translation norms can be either source-oriented (such as equivalence and literary norms) or target-oriented (such as didactic and pedagogical norms). According to pioneering translation scholar Gideon Toury, who includes inter-lingual adaptations in his definition of translation, all translations may be placed on an axis between adequacy-oriented (source-oriented) and acceptancy-oriented (target-oriented) translation (33-35, 56-57). For Toury, even the most adequacy-oriented translation contains shifts, because the occurrence of shifts is a basic characteristic of translation (57). Within translation studies, adaptation has been defined both as "a set of translative operations which result in a text that is not accepted as a translation but is nevertheless recognized as representing a source text" (Bastin 5), and as a reworking of the original author's text, using omission, rewriting, and addition (Milton 51). There are no definitive criteria for how much change is tolerated before a translation is considered an adaptation; what is accepted as a translation varies depending on time and place. All of the Montgomery translations discussed here are accepted as translations, but the early translations are clearly target-oriented, and could be termed adapted translations. As I will show, the target-orientation of the early translations results in censorship of important textual elements in deference to the target culture norms, while the more recent translations are adequacy-oriented, demonstrating greater interest in reflecting Montgomery's plot, character, and themes without fear of target-culture sensitivities. Thus, the later works exemplify a shift in the translation norms for children's classics.

The adaptations found in early Nordic translations of Rilla of Ingleside clearly censor source text materials because of their political nature. Censorship in translations is a type of adaptation defined as the influence of ideology on the translation and can be carried out on aesthetic, moral, political, military, and religious grounds (Merkle). Ideology is inseparable from literature and thus from the translation of literature, as Gaby Thomson-Wohlgemuth points out, but the nature of the connection varies (225). Censorship is motivated by a wish to create a cultural or political system or to protect the vulnerable, such as children (Merkle). The translators or publishers of the early Nordic translations of Rilla of Ingleside appear to have wanted to protect young readers from the horrors of war, and they also wanted to present the novel's warring nations in a light that reflected well upon the target country's role in recent wars. The translations thus transpose the attitudes and values of another culture and time into Rilla of Ingleside without changing the story's setting. The changes that reflect the time and place of the translations represent adaptation as commentary on the source text, as mentioned by Julie Sanders (18).

Censorship of perceived inappropriate elements in children's literature has been termed "purification," a term originally coined by Swedish educationalist 
and children's literature scholar Göte Klingberg, who defines this didactic strategy as adaptation to make the target text correspond with the values of the target readers or, in the case of children's literature, their parents and educators (58). Reasons for purification are similar to the reasons for censorship (Klingberg 58-59; Desmet 82). The term purification emphasizes the wish to present children with "pure" texts, while censorship has more political connotations. The war-related manipulation in the early Nordic translations of Rilla of Ingleside represents both aspects.

In these translations, the manipulation is purely self-censorship by the publishers or translators, since no government censorship was in place. Similar self-censorship has been described by Nitsa Ben-Ari, who analyzed manipulation of Christian elements in Hebrew translations of Ben Hur (1880) to convert a Christian story into a Jewish one. The early Nordic translations of Rilla of Ingleside exemplify self-censorship, because they are target-oriented and alter the author's messages to accommodate the ideology and sensibility of the target audience.

\section{Publication History of the Early Translations: Target-Oriented Censorship}

Sweden was the first country in the world to translate Anne of Green Gables (1908), and all the Anne books were translated into Swedish within a few years after the release of each original. Sweden was the first and only Nordic country to translate Rilla of Ingleside in the interwar years, fairly soon after the period described in the novel. Because of the early time of publication of the Swedish translation in 1928, this translation and its adaptation reflects Sweden's officially neutral status during the First World War. The Swedish translation was made by Axel G:son Söllberg (1896-1968) and is called Lilla Marilla ("Little Marilla"). ${ }^{5}$ It later served as source text for the other early Nordic translations.

The Norwegian translation called Anne og Marilla ("Anne and Marilla"), ${ }^{6}$ an abridged version of the Swedish translation, was made by Jo Tenfjord (1918-2007) ${ }^{7}$ and published in 1959, fifteen years after the Second World War. The Finnish translation, called Kotikunnaan Rilla ("Rilla of Home Hill"), an adapted version of the Swedish translation, was made by Kerttu Piskonen (1918-94) ${ }^{9}$ and published in 1962, four years after the Norwegian translation. In both countries, translation of Rilla of Ingleside was delayed until the publishers decided to retranslate or revise the old translations of the other Anne books. The postwar period was a time when publication of children's books, particularly translations, increased, at least in Norway (Birkeland et al. 151).

The Norwegian and Finnish translations were adapted for an audience still reeling from the horrors of the Second World War. During that war, Norway 
was occupied by Germany after relatively little resistance, because military preparedness was poor. The occupation lasted throughout the war and resulted in negative postwar attitudes toward Germans and the people who had collaborated with them. Finland was never occupied by Germany, but instead fought two wars against the Soviet Union, the Winter War and the Continuation War, between 1939 and 1944, resulting in Finland losing territory to the Soviet Union. During the Continuation War, Finland received help from Germany and became its ally and economic dependent (Gustavsson 260-71; Nordstrom 295-320). The countries' war history explains the late translation dates. During the German occupation of Norway, publication of a book like Rilla of Ingleside would have been prevented by Nazi censorship, and books about war were few (Birkeland et al. 147, 150). In the postwar years, war was not a popular subject in Norwegian or Finnish children's literature (Birkeland et al. 151-58; Rajalin 158). Publishers probably wanted to protect children from war at this time, so even when Rilla of Ingleside was translated, efforts were made to subordinate and even omit war themes.

The Swedish, Norwegian, and Finnish translations all appeared in publisher series - a common phenomenon in children's literature at the time (Warnqvist, "I Experienced" 229). Publisher series consisting of books selected and adapted to fit the series were easy and cheap to market, since the cover designs were similar, and the series targeted a specific gender and age group (Birkeland et al. 220; Heikkilä-Halttunen 415-16). Each book in the series could only have a predetermined number of pages. Thus, there was a commercial motivation to cut a certain amount of material; however, in the case of the early Nordic Rilla of Ingleside translations, the choice of what to cut was also political, at least in the war-related sections. These choices may have been made either by the publisher or the translator. Norwegian children's literature scholar Kari Skjønsberg has studied adaptations of children's literature in Norway and concluded that translators were free to make some choices, but that publishers often provided guidelines on how books should be adapted (40). Because the publisher has the final say, adaptation decisions cannot necessarily be attributed only to the translator.

The Swedish translation of Rilla of Ingleside was published by C.W.K. Gleerups Förlag ${ }^{10}$ as part of their series of young adult books called C.W.K. Gleerups ungdomsböcker (1899-1968, "C.W.K. Gleerup's young adult books"). The series was popular, and many of the books were reprinted several times (Warnqvist, "I Experienced" 229). In her archival research, Swedish Montgomery scholar Åsa Warnqvist has found that the Swedish translation of Anne of Green Gables published in the same series was abridged at the publisher's request to fit into the series, and this obviously applies to Rilla of Ingleside and all the other books in the Anne series as well ("Anne" 
214). According to Warnqvist, education and religion were central topics in Gleerup's catalog, and besides the young adult book series the company mainly published academic and religious works and textbooks (Warnqvist, "I Experienced" 229). This may have impacted their didactic criteria for choosing and adapting books for the series.

Like in Sweden, the Norwegian Anne books were published in a young adult book series requiring adaptation. The series by the publisher H. Aschenhoug \& Co. is called Aschenhougs utvalgte for piker (1939-61, "Aschenhoug's selection for girls"). The name of the series was typical of the period and appealed to adults buying books for children through the emphasis on quality (Birkeland et al. 89). The Finnish translation was published by Werner Söderström Oy (WSOY) in their young adult book series called Kuolemattomia nuortenkirjoja, sometimes also Kuolemattomia tyttökirjoja (1961-1982, "Immortal young adult books" or "Immortal girls' books"), later Ikivihreitä nuortenkirjoja (1992, "Evergreen young adult books") consisting of presumably adapted translations of English-language girls' classics.

Close comparison of the Swedish translation with the original text shows that the translation was adapted and abridged to fit the book into the publisher series and to reflect Swedish political neutrality during the time of translation. However, the abridgement is not acknowledged in any of the editions of the book. Thus, readers are not aware of the abridgement. It is not known whether the Norwegian publisher was aware of the abridgement when deciding to use the Swedish translation as source text. The reasons behind this choice may have been commercial, since the Swedish translation, printed in a similar series to the Norwegian, was already a commercial success, and furthermore, proficiency in English was not yet widespread in the Nordic countries, while proficiency in the linguistically closely related language Swedish was high in Norway. ${ }^{11}$

Another important factor in the abridgement and the political and warrelated cuts is that the books in the Nordic publisher series targeted younger audiences than Montgomery's original did. The Swedish translation of Rilla of Ingleside indicates on the back cover that the book is for girls aged twelve to sixteen years. The Norwegian translation targets even younger readers than the Swedish one, indicating the audience as girls aged nine to fourteen years. The Finnish publisher did not indicate any specific target age for their translation, but based on the adaptation, the target audience seems to be similar to that of the Swedish translation. All three translations exemplify a protective attitude toward children since they emphasize domesticity by foregrounding family relations rather than the wartime narrative. This is particularly evident in the Norwegian translation, which has the youngest target audience. 
The Norwegian translation of Rilla of Ingleside is even more abridged than the other translations: while the Swedish and Finnish translations are over 200 pages, the Norwegian is only about 130 pages long. Comparison with the original English text also reveals major abridgement of the Norwegian translation: all chapters omit chunks of text, and several chapters have been combined or completely omitted. My close examination of the Norwegian translation reveals that it is based on the Swedish translation rather than on the English original. Even the cover illustration seems to copy the Swedish 1940s cover, since both illustrations feature a young woman in a Red Cross uniform in the foreground and a soldier on the battlefield in the background. ${ }^{12}$ The Norwegian translation omits all the same passages as the Swedish version, and it makes similar small additions to the text and changes to chapter titles. Furthermore, the Norwegian translation makes many additional omissions to abridge the book to the page count required by the publisher series, and to adapt it for even younger readers by limiting discussion on the topic of war because of the recent difficult war years.

The Finnish translation of Rilla of Ingleside is the only one of the Nordic translations that is actually labeled as abridged, but neither the Finnish nor the Norwegian translation indicates the use of the Swedish version as the source language. Anna Suominen was the first to find that the Finnish translator has used both the Swedish translation and the English original as source texts and my research confirms that omissions, mistakes, and small additions are very similar (47). However, the Finnish translation contains some passages that are omitted in the Swedish translation, which proves that the English original text was also used. Additional omissions are also made concerning nationalities, which reveals more ideological principles at work

\section{References to the War and Nationalities in the Early Translations}

Commercial considerations may have been behind the shorter word count, but the Swedish version omits most of Montgomery's nuanced discussion of war and nationalities; this political and didactic choice transforms a simple act of translation into an act of censorship because Sweden's political position as a neutral country affected the transfer of Montgomery's messages into the Swedish target text. In the Swedish translation, most of the dialogue concerning the events on the warfront has been omitted. Only war news essential to the plot remains, which indicates plot-driven ${ }^{13}$ adaptation and increased insulation of the readers from the war. As a consequence, the majority of Susan's lines have been omitted, because the dialogue about war is usually in conversations between Susan and other characters such as Gertrude, the local school teacher boarding with the Blythes, Susan's cousin Sophia, the 
minister Mr Meredith, and Anne's husband Gilbert. Omissions include both very harsh and quite innocent comments about many different nationalities and historical persons. Examples range from Susan's imagining torturing the German Kaiser to Susan making fun of U.S. President Woodrow Wilson's famous notes. Some of these omissions of presumably foreign culture-bound elements may have been justified by pedagogical as well as political reasons.

The war-related omissions concern both the Allies and Germany to an almost equal extent, which perhaps reflects Swedish neutrality in the war. However, considering that all remarks about Germany in the original book are decisively negative while many remarks about the Allies are enthusiastically positive, the modifications in the Swedish translation shift the balance of the book's ethos in favor of Germany by toning down the anti-German comments. The translation exhibits less hostility toward other nationalities, but it may also reflect Sweden's cultural, intellectual, and commercial ties with Germany. Sweden favored Germany at the beginning of the First World War, despite its official neutrality (Gustavsson 240-47; Nordstrom 257-68).

A major purifying modification in the Swedish translation is of Susan's derogatory use of the term "Huns," which has been changed into the neutral "Germans" with only two exceptions where "Huns" is used metaphorically. Again, these alterations reflect Sweden's neutral position in the First World War and the neutral and slightly more German-friendly politics during the time of translation in the interwar years. Sweden was not anti-German at this time and had strong commercial ties to Germany, and the publisher probably did not want to encourage anti-German attitudes too much. At the same time, Swedish connections to Germany did not prevent the translation of this book as a sequel to the earlier, commercially successful Anne books. The neutralizing modifications and Sweden's neutrality actually made it possible to reprint the Swedish translation of Rilla of Ingleside even during the Second World War, because the translation is not as anti-German as the original, and above all because Swedish publishers could publish German-related content more freely than the other Nordic countries, since Sweden was neither occupied by nor allied to Germany at this time.

Because the Norwegian translation used the Swedish translation as its only source text, nationalities are treated in the same way, and the reference to "Germans" instead of "Huns" follows the Swedish pattern, omitting the strong anti-German sentiment. Ironically, the translation does not reflect the Norwegian postwar attitude, which, due to the German occupation during the Second World War and stronger economic ties to Britain, was more antiGerman than that of neutral Sweden in the 1920s. However, none of the many additional omissions in the Norwegian translation concern negative remarks about the Germans, which is not surprising. The additional omissions include 
war-related comments mentioning historical persons such as the Kaiser or General Haigh, similar to the Swedish omissions that move focus away from the war. If Montgomery's original had been used as source text, more of the anti-German comments might have been retained.

The 1962 Finnish translation also makes additional omissions in the warrelated passages compared to the Swedish translation. These minor omissions include mention of Germany, Germans, and the Kaiser, showing that the Finnish translation did not want to emphasize Germany as the enemy due to Finland's guilt by association as its ally in the Second World War. The Finnish translation also expresses a pacifist ideology typical of the 1960s and aims to avoid pitting nations against each other.

My analysis shows that while the Swedish and Norwegian translations use the neutral term "Germans" instead of "Huns," the Finnish translation rarely mentions the Germans. When lines mentioning Germans are not omitted in the Finnish translation, they are often modified. The Germans are referred to as "the enemy" or simply as "they," and sometimes paraphrasing is used. For example, in a line stating that "the Huns have broken through" (138), "Huns" is substituted by "tyskarna" / "tyskerne" ("the Germans" 115/5914) in the Swedish and Norwegian translations and by "vihollinen" ("the enemy" 105) in the Finnish translation. In some cases, such as when Susan compares her rheumatism to "being gassed by the Huns" (135), the Swedish and Norwegian translations omit "Huns" as the agent, while the Finnish translation makes a comparison to "sotilaiden kärsimyksiin" ("the suffering of the soldiers" 103). This ideological purification reflects that the Finnish translation does not want to emphasize the nationality of the enemy. Similarly, references to the British are omitted, or they are referred to as "our people." These blurring modifications concerning nationalities not only reflect Finland's position as an ally of Germany only two decades earlier, but also the anti-war atmosphere of the 1960s and the Cold War period. Who "we" and "they" are is considered less important. Interestingly, the sentences "the Russians will not be in time to save Paris" (79) and "the Germans are in Paris" (96) are both translated with a passive structure simply as "Pariisi on mennyttä kalua" / "Pariisi on mennyt" ("Paris is lost" 64, 78), illustrating that Russians are treated differently from other nationalities. Negative remarks about Russians are maintained, while remarks about Russians with positive connotations are omitted. This reflects the fact that Russia was Finland's enemy during the Second World War and that Finland's relationship with the Soviet Union was still strained in the 1960s, resulting in strong anti-Russian sentiment at this time.

The more neutral treatment of nationalities in the Swedish translation (and consequently in the Norwegian translation, despite Norway's different history) downplays Montgomery's patriotic message and teaches children respectful 
treatment of other nationalities even when they are the enemy. The Finnish translation blurs the different nationalities and downplays Montgomery's patriotic message even more to send children a more pacifistic message by avoiding emphasis on any particular nationality as the enemy. Thus the translations not only clearly reveal their political viewpoints but also reflect ideologies dominating the realities of their young target readers.

\section{Pacifism in the Early Translations}

The translations also take different stands on the war-related phenomenon of pacifism represented in Rilla of Ingleside through the character of Mr Pryor. Most war-related negative references to the supposedly pro-German pacifist Mr Pryor have been omitted in the Swedish translation, including the entire chapter "Norman Douglas Speaks Out," where Norman, a respected, strongminded member of the community, assaults Mr Pryor for a pacifist prayer that he says in church. Thus, the Swedish translation avoids the question of pacifism. Although pacifism can be considered to be in line with neutrality, the Swedish translator or publisher chose to omit Montgomery's anti-pacifist message instead of altering it.

In the Norwegian translation, almost all mention of Mr Pryor is omitted, resulting in further avoidance of the concept of pacifism. This unjustly shunned pacifist character was probably considered too complicated for the young target readers, because the concept of pacifism is never properly explained in the original novel. In the Norwegian translation Mr Pryor plays a significant role only in one scene, where he proposes to Susan and she chases him out of her kitchen with a pot. ${ }^{15}$ This scene was probably kept in the translation for its comic effect, while other omissions related to Mr Pryor may be motivated by the wish to protect children from ethically complicated matters through purification. The only subsequent mention of Mr Pryor in the Norwegian translation describes him having had a stroke, interpreted by some members of the community as punishment for his pacifism. Inclusion of this episode in the translation is not consistent with the other omissions of elements considered too harsh for the target readers.

In the Finnish translation, Mr Pryor and his pacifism is presented in a more positive light than in the Swedish and Norwegian translations. This probably reflects the time of translation in the 1960s during the Cold War, when the international peace movement was strong in the Nordic countries (Gustavsson 274-81; Nordstrom 321-30). "Pacifist" is never used as an abusive term as it is in the source text and in both the Swedish and Norwegian translations. In the Finnish translation, Mr Pryor is called, for example, "vanha törkimys" ("that old scruff" 196) instead. References to Mr Pryor are omitted less often 
in the Finnish translation but the harsh treatment he receives is toned down or omitted. For example, Susan's comment that one can have one's own thoughts about his paralytic stroke, insinuating that she thinks he deserved it, has been omitted. The Finnish translation shows pacifistic tendencies also in other contexts by emphasizing hatred towards the phenomenon of war instead of toward other nationalities by changing comments such as that the most important thing is "that the Allies win the war" (148) to "että kestämme sodan" ("that we endure the war" 113).

In line with 1960s attitudes, the Finnish translation presents pacifism in a more positive light and thus alters Montgomery's anti-pacifist message. This could also have been done in the Swedish and consequently in the Norwegian translation, but at the Swedish time of translation in the 1920s there was no political movement supporting such a drastic change, so instead the negative message was omitted.

\section{Female Heroism in the Early Translations}

As a result of the war-related omissions in the Swedish translation, Susan is portrayed only as a comic and domestic character instead of as a developing feminist character, which reduces and constrains the description of female heroism in the novel and places her more strictly within the feminine domain. In the English original, Susan clearly steps outside the domestic sphere by learning about geography and following the war news, which would have been considered masculine activities at the time when the narrative takes place. The Swedish translation omits Susan's constant optimism and independent opinions about how the war should be fought as well as her learning process, which Montgomery uses to express her loyalty and patriotism. Her only speeches containing war commentary included in the translation consist of lines that have a comic effect or are essential to the plot. Included, for example, is a silly war-related comment that emphasizes Susan's lack of education: she expresses distrust in British General Haigh because Rilla's brother Walter did not receive the Victoria Cross. (Only the Norwegian translation omits this line.) Generally, the Swedish translation emphasizes Susan's lack of education while omitting the original's description of her learning process. After one of Susan's lengthy comments on the war in the original, abridged to only one sentence in the Swedish translation, the translator or publisher has even felt compelled to add a clause where Susan "med storartad ödmjukhet" ("very humbly") admits that she is "ingen krigsexpert" ("no expert on war" 182). This section is completely omitted in the Norwegian translation, while the Finnish translation leaves out the Swedish addition. Another disparaging remark that has been added to all three translations is that Susan is found sitting 
in the kitchen "med odiskade tallrikar och fat" / "med skitne tallerkener og fat" / "pesemättömien astioiden keskellä" ("surrounded by unwashed dishes" 204/100/183) after finding out Anne's youngest son is enlisting.

Susan's role as a comic character is further emphasized in the Swedish translation by preserving non-war-related comic scenes such as her struggles with the family's cat Mr Hyde, or Susan whispering the wrong election results to Anne, who is already in bed, encouraging readers to laugh at her "simple" character. Many of the translated war comments are of a domestic or religious nature, such as when Susan comments on the Russian politician Alexander Kerensky's marriage, or when she finds passages she considers descriptive of Germans in the Bible. These comments were probably not seen as threatening, since they are associated with the home front rather than the warfront and are strictly linked to traditionally feminine domains. These comments were probably also kept for their comic effect.

In the original, Susan's heroism is connected to her patriotism. In the Swedish translation, the part of Susan's patriotism that is not directly hostile or anti-German has been preserved. Thus her heroism is not entirely omitted, but it is only connected to symbolic patriotism and not to female development. For example, the included passage comparing Susan standing on a load of grain as having the same spirit as the men at the front clearly describes her as a symbol of patriotism. Susan's speech at the Victory Loan Campaign meeting where she orders men to subscribe and, as Rothwell notes, takes a public politicized role, is also mostly unchanged (138). However, the translation never calls Susan a heroine, as she is in the original text. Although these two scenes, in which Susan steps into the men's world, are almost unchanged, their comic elements are emphasized at the expense of any feminist interpretation, because the other omissions have reduced Susan to a comic character, making these symbolic expressions of patriotism with masculine characteristics less threatening. The reduction of Susan, a strong female character in the original, to a comic character makes her character less complex and shifts narrative focus to Rilla alone.

In the Norwegian translation, which is based on the Swedish translation, Susan's role is even more reduced, which means that a female character that could have been a role model for the readers is almost completely omitted. Even her characterization as a comic foil is abridged. Mr Pryor's proposal is one of only a handful of Susan's comic scenes or lines left in the translation. Despite the further omissions, the nature of her characterization as a patriotic and domestic character remains about the same as in the Swedish translation. Additional omissions include an emotional scene when Susan finds out that Shirley, her favorite of Anne's children, is going to war, which shows Susan's emotional and vulnerable side in Montgomery's original. As a result of all 
the omissions, Susan becomes a peripheral and extremely flat character in the Norwegian translation.

In the Finnish translation, the characterization of Susan is similar to that of the Swedish translation, but her patriotism is toned down, because it was not in line with the 1960s peace movement. Her most patriotic comments, such as her faith that the Allies will win the war (included in the Swedish translation), are omitted, and the heroic description of Susan standing on a load of grain is adapted by omitting the comparison of Susan with the men at the front, thus losing the parallel to war heroism. The description of her heated patriotic speech at the Victory Loan Campaign meeting is also slightly edited, since her line about women like her standing behind British Prime Minister Lloyd George is omitted. This is a minor edit, but it reduces the emphasis of the patriotic key point of the speech and is probably made for pedagogical reasons to avoid repeating a name unfamiliar to Finnish readers. These modifications made in the Finnish translation to tone down Susan's patriotism contribute to blurring the message of her female heroism even more by omitting the parallels between her and the men at the front.

All three early Nordic translations reduce the role of Susan and her female heroism in different ways. This results in a closer focus on Rilla as the only heroine of the book, while Montgomery's original presents Susan as a parallel and contrast to Rilla. Rilla is a very conventional girls' book heroine who undergoes a development and maturation process to eventually end up married to the man she desires, staying very strictly within the female gender role of her time. Susan's development, on the other hand, takes her outside her domestic gender role, since she learns and expresses opinions about politics, a traditionally masculine domain. The minimization of Susan's role to a comic and one-dimensional character in the early Nordic translations means that female heroism is only depicted in traditionally feminine terms as Rilla's efforts with her war baby and Red Cross work, and that the translations provide fewer role models for their young female readers than the original. Therefore the early Nordic translations present the female gender role as more restricted than the original, which teaches young readers a more limited perception of gender roles.

\section{The Modern Danish and German Translations as Examples of Source-Oriented Translation Norms}

The modern Danish and German translations contrast with the early Nordic translations due to their later time of translation. They indicate a shift in translation norms from the target-oriented early translations, which featured political and gender-related censorship, to source-oriented, uncensored 
translations. Denmark, the fourth Nordic country included in this analysis, did not publish a translation of Rilla of Ingleside until 1993. The late date of the translation cannot be directly attributed to political reasons, because, in contrast to the other Nordic countries discussed here, the early translations of earlier Anne books did not gain the same popularity in Denmark as they did in the neighboring Nordic countries, and Rilla of Ingleside was not the only untranslated Anne book. In Denmark, the Anne series did not become popular until the first book was retranslated in 1987, right after Sullivan Entertainment's Anne of Green Gables (1985) television miniseries became a success in Denmark as it did in many other countries. In Germany, too, the translation of the Anne series was prompted by the miniseries from 1986 onwards, and included Rilla of Ingleside in 1995-96. Thus, the high degree of anti-German content is not the only reason for the late translation of Rilla of Ingleside into German. ${ }^{16}$

The Danish translation of Rilla of Ingleside made by Ida Elisabeth Hammerich (1930-2007) is called Anne-Børnene flyver fra reden ("Anne-the children leave the nest") while the German translation made by Dagmar Weischer was originally published in two parts with the titles Anne \& Rilla: Zum ersten Mal Verliebt (1995, "Anne \& Rilla: First time in love") and Anne \& Rilla: Der Weg ins Glück (1996, “Anne \& Rilla: The road to happiness"). ${ }^{17}$ Both the Danish and German titles capitalize on the success of the Anne brand, while the German titles also indicate a focus on romance. Neither the Danish nor the German translation is part of a publisher series, as the early translations were, but they are strongly marketed as part of the Anne series. Anne is mentioned in the titles to emphasize that the novel is an Anne book even though she is only a minor character in this book. To maintain the fiction of Anne's centrality, both translations reduce the distance Montgomery creates between Anne and the narrator, and consequently the reader. Rather than calling Anne and her husband Mrs Blythe and Dr Blythe as in the source text, the narrator of both Danish and German translations refers to her and Gilbert by their first names, as was done already in the Norwegian translation. Thus, the modern translations indicate that marketing forces play a stronger role than in earlier translations.

Apart from the titles and other minor modifications, the Danish and German translations closely adhere to Montgomery's original text. These translations are governed by more adequacy-oriented (source-oriented) translation norms, since they make few omissions and are not affected by Denmark's and Germany's war history as the early Nordic translations were. Neither translation makes any modifications concerning nationalities, and Germans are referred to as "Huns," exactly as in the source text. In the Danish translation, this should be interpreted only as a source-oriented translation following equiva- 
lence norms and not as a reflection of any continuing anti-German attitude despite Denmark's occupation by Germany during the Second World War. In the case of the German translation too, the rendering of anti-German sentiment in accordance with the source text is evidence of the source-oriented translation strategy. These translations may be interpreted as an ideological change toward greater respect for other cultures' points of view and a shift away from the view that children need to be protected from uncomfortable reality by purifying texts. They also reflect feminist ideology in that the description of gender roles is not changed.

Although the Danish translation makes some omissions compared with the source text, these seem to be due to the fact that the translator used a U.S. Bantam-Seal edition $(1985)^{18}$ of the original as source text rather than a complete early edition. This is most likely due to the high international availability and lack of awareness of changes made to this edition. The omissions in the Bantam-Seal editions and consequently in the Danish translation are so few that they do not significantly change the description of the war or impact gender roles. Most of the war-related omissions expurgate the text by omitting swearing or references to violence or death, but some also concern negative attitudes toward Americans. ${ }^{19}$ These minor omissions in the Danish translation reflect American rather than Danish attitudes. Like the Norwegian translation based on the Swedish translation, this is another example of how hidden adaptation in one edition or translation can unintentionally affect other subsequent versions of the text. The Danish translator would probably not consciously have made any of the American omissions, considering that her global translation strategy is very source-oriented.

Regarding the German translation, close comparative analysis shows that the original source text has been used rather than a Bantam-Seal edition, and that omissions are very few and never longer than one sentence. ${ }^{20}$ The German translation closely renders all the anti-German sentiment, and the only German-associated insult that has been changed is Norman Douglas calling Mr Pryor "Hunnish scum" (224), which has been translated neutrally as "Barbar" ("barbarian" 273). It is understandable that a German translation would not use a synonym for "German" as an insult. The German translation confirms what is seen already in the Danish translation: since the 1990s, the translation norms of children's literature have changed, and concerns about representing early twentieth century political history no longer influence translations. This shows that today norms of equivalence override didactic norms that previously resulted in political or gender-related censorship, at least when enough time has passed after the events described.

Comparison of the early adapted and abridged Swedish, Norwegian, and Finnish translations with the more recent complete Danish and German 
translations shows that the older translations are outdated because of the change in translation norms. Retranslations are called for to convey to the target readers Montgomery's original messages about diverse female heroism and the First World War from a patriotic Canadian perspective. In light of comparison with the original, the adapted and abridged translations can be seen as documenting the political situation and perceptions of gender roles in the Nordic countries at the time of translation and as commentaries on Montgomery's novel.

Laura Leden is a Ph.D. candidate at the University of Helsinki and holds an M.A. in Swedish Translation Studies and a B.A. in Scandinavian Literature. Her dissertation examines norms and adaptation in Swedish and Finnish translations of girls' books. She has published a paper on L. M. Montgomery in the children's literature journal The Looking Glass and presented several papers at the L. M. Montgomery Conference organized by the University of Prince Edward Island.

\section{Notes}

${ }^{1}$ The posthumously published book The Blythes Are Quoted (2009) can be considered the ninth book in Montgomery's Anne series.

${ }^{2}$ Iceland is the only Nordic country not to have a translation of Rilla of Ingleside, despite the fact that four Anne books were translated into Icelandic in 1933-45.

${ }^{3}$ The comparative analysis of the translations in this paper considers only sections involving Susan; no full comparison of the translations has been carried out.

${ }^{4}$ All page references for quotes from Montgomery's original Rilla of Ingleside refer to the 2010 complete special edition.

${ }^{5}$ Marilla is the full name of Rilla, named after Anne's adoptive mother Marilla Cuthbert, who is an important character in the early Anne books. The Swedish title may create some confusion, and those not familiar with the earlier books may interpret it as a diminutive, which is common in girls' books.

${ }^{6}$ The title Anne og Marilla ("Anne and Marilla") is similar to the Swedish title, because Rilla is again referred to as Marilla, but the Norwegian title emphasizes that the book is part of the Anne series by including Anne's name, as do all titles of the Norwegian Anne books. Anne's name clearly has commercial value, and thus this shift can be labeled marketing-related commercial adaptation. The Norwegian translation also strives to bring Anne and Gilbert, characters from the earlier books, closer to its readers by having the narrator refer to them by their first names, rather than as Mrs 
Blythe and Dr Blythe, as in the original text and the Swedish translation. In the original, the use of these titles emphasizes the change of protagonist from Anne to Rilla.

${ }^{7}$ Jo Tenfjord was an influential person in Norwegian children's literature of her time. She was a librarian, author of girls' books, member of the International Board on Books for Young People (IBBY), and the most productive children's book translator in Norway in the postwar period (Birkeland et al. 160-61).

${ }^{8}$ In contrast to the other translations of the title, Kotikunnaan Rilla ("Rilla of Home Hill") can be considered an adequate translation of the original title.

${ }^{9}$ Kerttu Piskonen was employed as a clerk by the publisher WSOY and Rilla of Ingleside was one of her first translations, though she went on to translate several children's books (Niemi). This indicates that she probably worked in close cooperation with the publisher during her translation process.

${ }^{10}$ In the 1970 s, Gleerup was incorporated into the publisher Liber and the translations of Montgomery's books underwent linguistic revision to modernize the language. In the 1990s, the Swedish publication rights of Montgomery's books were acquired by Norstedt.

${ }^{11}$ The Scandinavian languages Swedish, Norwegian, and Danish are mutually understandable to native speakers. In Finland, proficiency in Swedish was high because Swedish is the second official language in Finland as a result of the country's shared history with Sweden.

${ }^{12}$ These war settings seem strange cover choices, considering that the translations downplay the war and are aimed at young audiences.

${ }^{13}$ According to Zohar Shavit, the plot is the most important element in children's literature, and therefore, when translators need to abridge a text, they usually omit passages that do not contribute to the plot in its narrowest sense $(122,124)$. The early Nordic translations of Rilla of Ingleside exemplify this attitude by strictly focusing on one main plot, the struggles of Rilla on the home front, while minimizing description of events on the warfront and almost completely omitting the sub-plot related to Susan.

${ }^{14}$ All page references for quotes from the translations refer to the edition of the translation listed in the bibliography.

${ }^{15}$ Epperly suggests that this scene represents a comic miniature of the German defeat (127), but this may be lost to the readers of translations where Susan's role is reduced.

${ }^{16}$ According to Martina Seifert, Anne of Green Gables was not considered for translation into German before the 1980s because Montgomery's books conflicted with the German image of Canada as a northern wilderness associated with wild 
animals and masculinity (331). This image was strengthened by the fact that almost all Canadian books published in Germany up to the 1980s were adventure stories with male protagonists and male authors (331).

${ }^{17}$ The first part ends after Rilla's engagement to Kenneth Ford. In 2001, both books were published as one Big Book paperback under the title Anne \& Rilla: Zum ersten Mal verliebt by the publisher Arena.

${ }^{18}$ Seal Books was a partnership between American Bantam Books and Montgomery's Canadian publisher McClelland and Stewart. The same edition of Rilla of Ingleside has appeared under both Bantam Books and Seal Books, and thus I and other scholars such as Lefebvre and McKenzie refer to these editions as the Bantam-Seal editions.

${ }^{19}$ According to Lefebvre and McKenzie, the Bantam-Seal editions cut four percent of the text $(\mathrm{xx})$. The omissions in the Danish translation are the same as those of the Bantam-Seal editions. Most of the war-related omissions expurgate the text by omitting swearing or references to violence or death. Some omissions are related to religion, such as when Mr Pryor considers it a good thing that a Catholic church was burned down or when Susan and Cousin Sophia argue about the role of God in the war. These passages are omitted in the other, earlier, Nordic translations as well. Some of the omissions are passages where Susan mentions the United States or president Woodrow Wilson in a negative light, which is explained by the fact that the omissions were originally made by an American publisher, the American Reprint Company specializing in reprinting out-of-copyright books. The company published a hardcover edition in 1976 and that version was reissued by Bantam-Seal in 1985 and has been reprinted continuously since then (Lefebvre and McKenzie xx). It is not that surprising that the American Reprint Company made some omissions, since Stokes, Montgomery's original American publisher, had already asked Montgomery to "omit or tone down some of the shadows" and "taffy up" the description of the United States during the war, which Montgomery refused to do (Montgomery, Selected Journals II 404). Some American readers did not take kindly to this. Edwards notes that American reviewers were condescending toward Susan because of her hostility toward the United States (133).

\footnotetext{
${ }^{20}$ Most of the omissions in the German translation are insignificant. They include redundant information repeated elsewhere and minor cultural or linguistic elements that are difficult to translate, for example, Susan's struggles with the pronunciation of foreign names that are not difficult for German readers. These kinds of minor omissions are quite common even in modern translations that otherwise avoid the strategy of omission. There are only a few war-related shifts and most of them relate to insulting Mr Pryor. It seems that the German translator wanted to avoid the word pacifist in connection with insults, because "pacifist pig" (207) has become "Hausschwein" ("domestic pig" 252) and Mr Pryor's controversial prayer is referred to as a "Friedensappell" ("peace appeal" 272) rather than a "pacifist appeal" (223).
} 


\section{Works Cited}

Bastin, Georges L. "Adaptation.” Routledge Encyclopedia of Translation. Ed. Mona Baker. London: Routledge, 1998. 5-8. Print.

Ben-Ari, Nitsa. "The Double Conversion of Ben-Hur: A Case of Manipulative Translation.” Target 14.2 (2002): 263-301. Print.

Birkeland, Tone et al. Norsk barnelitteraturhistorie [Norwegian children's literature history]. Oslo: Det Norska Samlaget, 1997. Print.

Desmet, Mieke K. T. "Babysitting the Reader: Translating English Narrative Fiction for Girls into Dutch (1946-1995). " Diss. London University Collage, 2002. Bern: Peter Lang, 2007. Print.

Desmidt, Isabelle. "A Prototypical Approach within Descriptive Translation Studies? Colliding Norms in Translated Children's Literature.” Children's Literature in Translation: Challenges and Strategies. Ed. Jan Van Coillie and Walter P. Verschueren. Manchester: St. Jerome P, 2006. 79-96. Print.

Edwards, Owen Dudley. “L.M. Montgomery's Rilla of Ingleside: Intention, Inclusion, Implosion." Harvesting Thistles: The Textual Garden of L.M. Montgomery. Essays on Her Journals. Ed. Mary Henley Rubio. Guelph: Canadian Children's P, 1994. 126-36. Print.

Epperly, Elizabeth Rollins. The Fragrance of Sweet-Grass: L.M. Montgomery's Heroines and the Pursuit of Romance. Toronto: U of Toronto P, 1993. Print.

Gustavsson, Harald. Nordens historia: En europeisk region under 1200 år [History of the Nordic Countries: A European region for 1200 Years]. Lund: Studentlitteratur, 2007. Print.

Heikkilä-Halttunen, Päivi. Kuokkavieraasta oman talon haltijaksi: Suomalaisen lastenja nuortenkirjallisuuden institutionalisoituminen ja kanonisoituminen 1940-1950-luvulla [From a gatecrasher to the owner of the house: The institutionalization and canonization of Finnish children's and young adult literature in the 1940s to 1950s]. Diss. U of Tampere, 2000. Helsinki: Finnish Literature Society (SKS), 2000. Print.

Klingberg, Göte. Children's Fiction in the Hands of Translators. Studia psychologica et paedagogica 82. Series altera. Lund: Gleerup, 1986. Print.

Lefebvre, Benjamin, ed. The L.M. Montgomery Reader. Volume 3: A Legacy in Review. Toronto: U of Toronto P, 2015. Print.

Lefebvre, Benjamin, and Andrea McKenzie. "A Note on the Text." Rilla of Ingleside. Ed. Benjamin Lefebvre and Andrea McKenzie. Toronto: Viking Canada, 2010. xx. Print.

McKenzie, Andrea. "Women at War: L.M. Montgomery, the Great War, and Canadian Cultural Memory." Storm and Dissonance: L.M. Montgomery and Conflict. Ed. Jean Mitchell. Newcastle: Cambridge Scholars P, 2008. 83-108. Print. 
Merkle, Denise. "Censorship.” Handbook of Translation Studies Online. Ed. Yves Gambier and Luc van Doorslaer. John Benjamin: Amsterdam, 2011. Web. 23 Apr. 2016.

Milton, John. "Translation Studies and Adaptation Studies.” Translation Research Project 2. Ed. Anthony Pym and Alexander Perekrestenko. 51-58. Web. 23 Oct. 2016.

Montgomery, L. M. Anne \& Rilla: Zum ersten Mal Verliebt. Zwei Romane in einem Band [Anne \& Rilla: First time in love. Two novels in one book]. Trans. Dagmar Weischer. Würzburg: Arena, 2001. Print.

- Anne-Børnene flyver fra reden [Anne-The children leave the nest]. 1993. Trans. Ida Elisabeth Hammerich. Copenhagen: Høst 2008. Print.

_. Anne og Marilla [Anne and Marilla]. Trans. Jo Tenfjord. Oslo: Aschenhoug, 1959. Print.

_. Kotikunnaan Rilla [Rilla of Home Hill]. 1962. Trans. Kerttu Piskonen. Helsinki: WSOY, 1993. Print.

_. Lilla Marilla [Little Marilla]. 1928. Trans. Axel G:son Söllberg. Malmö: Gleerup, 1970. Print.

—. Rilla of Ingleside. 1921. Seal Books, 1996. Print.

- Rilla of Ingleside. Ed. Benjamin Lefebvre and Andrea McKenzie. Toronto: Viking Canada, 2010. Print.

- The Selected Journals of L.M. Montgomery. Volume II: 1910-1921. 1987. Ed. Mary Rubio and Elizabeth Waterston. Toronto: Oxford UP, 1997. Print.

Niemi, Seija A. "Sylvi, Lahja ja Kerttu Piskosen rahasto kotimaisen lasten- ja nuortenkirjallisuuden tukemiseen" [Sylvi, Lahja and Kerttu Piskonen Foundation for Finnish children's and young adult literature]. Finnish Cultural Foundation. Web. 20 June 2016.

Nordstrom, Byron J. Scandinavia since 1500. Minneapolis: U of Minnesota P, 2000. Print.

Rajalin, Marita. "Sodan jälkiä” [Traces of the War]. Pieni suuri maailma: Suomalaisen lasten- ja nuortenkirjallisuuden historia [Little big world: The history of finnish children's and young adult literature]. Ed. Liisi Huhtala et al. Helsinki: Tammi, 2003. 158-61. Print.

Rothwell, Erika. "Knitting Up the World: L. M. Montgomery and Maternal Feminism in Canada." L.M. Montgomery and Canadian Culture. Ed. Irene Gammel and Elizabeth Epperly. Toronto: U of Toronto P, 1999. 133-44. Print.

Sanders, Julie. Adaptation and Appropriation. London: Routledge, 2006. Print.

Seifert, Martina. "Conflicting Images: Anne of Green Gables in Germany." Storm and Dissonance: L.M. Montgomery and Conflict. Ed. Jean Mitchell. Newcastle: Cambridge Scholars P, 2008. 228-343. Print.

Shavit, Zohar. Poetics of Children's Literature. Athens, GA: U of Georgia P, 1986. Print. 
Skjønsberg, Kari. Vem berättar? Om adaptioner i barnlitteratur [Who Tells the Stories? About Adaptations in Children's Literature]. Trans. Ying Toijer-Nilsson. Stockholm: Rabén \& Sjögren, 1982. Print.

Suominen, Anna. "New Time, New Readers, New Rilla: Changes in the Finnish and Swedish Translations of Rilla of Ingleside by L. M. Montgomery." MA thesis University of Helsinki, 2011. Web. 23 Oct. 2016.

Thomson-Wohlgemuth, Gaby. Translation under State Control: Books for Young People in the German Democratic Republic. London: Routledge, 2009. Print.

Toury, Gideon. Descriptive Translation Studies and Beyond. Amsterdam: John Benjamin, 1995. Print.

Warnqvist, Åsa. “Anne på Grönkulla - 'en af de nöjsammaste bekantskaper man kan göra': Utgivning och mottagande av L.M. Montgomerys verk i Sverige" ["Anne of Green Gables-'one of the most amusing acquaintances to get to know"”: Publication and reception of L.M. Montgomery's works in Sweden]. I litteraturens underland [In the wonderland of literature.] Ed. Maria Andersson et al. Gothenburg: Makadam, 2011. 212-29. Print.

_. "“I Experienced a Light that Became Part of Me': Reading Anne of Green Gables in Sweden." Anne around the World: L.M. Montgomery and Her Classic. Ed. Jane Ledwell and Jean Mitchell. Montreal: McGill-Queen's UP, 2013. 228-42. Print.

Waterston, Elizabeth. Magic Island: The Fictions of L.M. Montgomery. Don Mills: Oxford UP, 2008. Print.

Waterston, Elizabeth, and Kate Waterston, ed. Readying Rilla: L.M. Montgomery's Reworking of Rilla of Ingleside. Oakville: Rock's Mills P, 2016. Print. 